\title{
ANALISIS KEMAMPUAN PEMECAHAN MASALAH SISWA PADA SOAL STATISTIKA BERSTANDAR UJIAN NASIONAL
}

\author{
(ANALYSIS OF STUDENTS' PROBLEM SOLVING ABILITY IN \\ STATISTICS PROBLEMS OF NATIONAL EXAMINATION STANDARD)
}

\author{
Melhan Eka Putri Mardatillah ${ }^{1}$, Baiq Rika Ayu Febrilia ${ }^{2}$, Zainal Abidin ${ }^{3}$ \\ ${ }^{1}$ Program Studi Pendidikan Matematika, Universitas Pendidikan Mandalika, \\ imel290597@gmail.com \\ ${ }^{2}$ Program Studi Pendidikan Matematika, Universitas Pendidikan Mandalika, \\ rikafebrilia@ikipmataram.ac.id \\ ${ }^{3}$ Program Studi Pendidikan Matematika, Universitas Pendidikan Mandalika, \\ matstatenal@gmail.com
}

\begin{abstract}
Abstrak
Penelitian ini bertujuan untuk menganalisis kemampuan pemecahan masalah siswa dalam menyelesaikan soal statistika berstandar Ujian Nasional (UN) berdasarkan tahapan Polya. Jenis penelitian ini adalah kualitatif deskriptif dengan metode kualitatif yang melibatkan 6 siswa kelas XI IPA dengan masing-masing dua subjek memiliki kemampuan awal matematika rendah, sedang, dan tinggi. Instrumen yang digunakan terdiri atas tiga soal statistika berstandar ujian nasional. Hasil penelitian ini menunjukkan bahwa sebagian besar siswa hanya memiliki kemampuan pemecahan masalah hingga pada tahap memahami masalah. Bahkan, salah satu siswa pada kategori rendah tidak bisa menyelesaikan semua soal atau dengan kata lain, kemampuan pemecahan masalah siswa sangat rendah untuk semua subjek yang terlibat. Perlu adanya penelitian lebih jauh untuk menjelaskan penyebab rendahnya kemampuan pemecahan masalah siswa ini.
\end{abstract}

Kata kunci: Kemampuan Pemecahan Masalah, Statistika,Ujian Nasional

\begin{abstract}
This study aims to analyze students' problem-solving abilities in solving statistical questions with the National Examination (UN) standard based on the Polya stages. This type of research is qualitative descriptive with qualitative methods involving 6 students of class XI IPA with two subjects each having low, medium, and high initial mathematics abilities. The instrument used consists of three statistical questions with national examination standards. The results of this study indicate that most students only have problem-solving skills to the point of understanding the problem. In fact, one student in the low category could not solve all the questions or in other words, the student's problem solving ability was very low for all the subjects involved. Further research is needed to explain the causes of these students' low problem-solving abilities.
\end{abstract}

Keywords: Problem Solving Ability, Statistics, National Examination 


\section{PENDAHULUAN}

Jika dilihat dari aspek kurikulum, kemampuan pemecahan masalah dalam pembelajaran matematika menjadi salah satu tujuan dalam pembelajaran matematika di sekolah yaitu melatih cara berpikir dan bernalar dalam menarik kesimpulan, mengembangkan kemampuan memecahkan masalah, serta mengembangkan kemampuan menyampaikan informasi atau mengkomunikasikan ide-ide melalui lisan, tulisan, gambar, grafik, peta, diagram, dan sebagainya (Depdiknas, 2006). Berkenaan dengan pentingnya kemampuan pemecahan masalah, National Council of Teacher of Mathematics (NCTM) mengatakan bahwa dalam pelaksanaan pembelajaran matematika di sekolah, guru harus memperhatikan lima kemampuan matematika yaitu: koneksi (conections), penalaran (reasoning), komunikasi (communications), pemecahan masalah (problem solving), dan representasi (representations) (NCTM, 2000). Oleh karena itu, guru memiliki peranan yang sangat penting dalam menumbuhkan kemampuan pemecahan masalah matematis dalam diri siswa baik dalam bentuk metode pembelajaran yang dipakai, maupun dalam evaluasi berupa pembuatan soal yang mendukung. Polya (1973) mengemukakan pemecahan masalah merupakan suatu usaha yang akan dilakukan oleh siswa dalam mencari jalan keluar atas kesulitan yang sedang dihadapi. Adapun indikator kemampuan pemecahan masalah matematika yang dikemukakan oleh Polya yaitu, (1) memahami masalah, (2) merencanakan pemecahannya, (3) menyelesaikan masalah sesuai rencana, (4) memeriksa kembali prosedur dan hasil penyelesaiannya.

Berdasarkan hasil penelitian yang dilakukan oleh Sapitri, Utami \& Maryam (2019), siswa dengan kemampuan pemecahan masalah yang tinggi memiliki minat belajar tinggi, siswa berkemampuan sedang memilik kemampuan pemecahan masalah sedang dan siswa yang berkemampuan rendah memiliki kemampuan pemecahan masalah rendah. Kemampuan pemecahan masalah siswa dalam menyelesaikan soal rata-rata hitung tergolong baik. Hal ini ditunjukkan dari 24 siswa, terdapat 16 orang dapat menjawab soal dengan benar. Mereka mampu (1) mengidentifiasi unsur-unsur yang diketahui, ditanyakan dan kecukupan unsur yang diperlukan, (2) merumuskan masalah matematika atau menyusun model matematis, (3) menerapkan strategi untuk menyelesaikan masalah, (4) menjelaskan atau menginterpretasikan hasil penyelesaian masalah (Wiwin \& Mogi, 2016).

Berdasarkan hasil survey internasional Program for International Student Assessment (PISA) tahun 2012, ranking Indonesia dalam kemampuan matematika menempati peringkat 64 dari 65 negara peserta PISA (PISA, 2012). Pada tahun 2015, Indonesia menempati peringkat 63 dari 70 negara peserta PISA dalam kemampuan matematika (PISA, 2015). Hasil ini disajikan pada Gambar 1. 


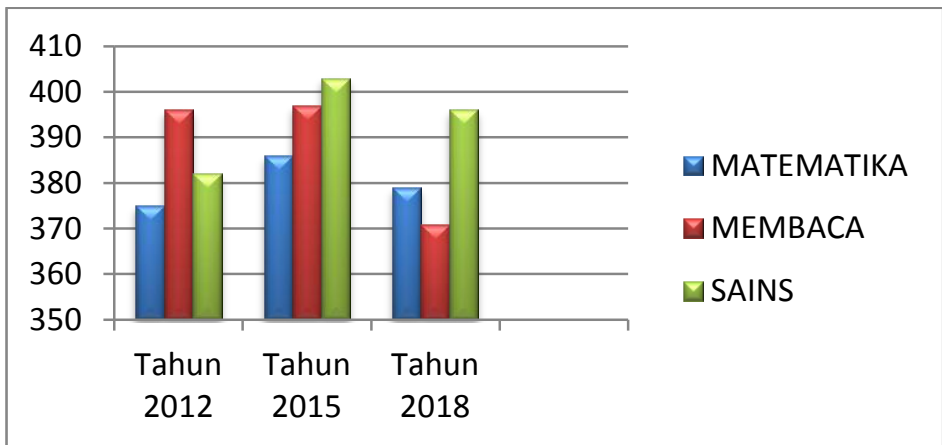

Gambar 1. Kemampuan Matematika Indonesia tahun 2012, 2015, 2018 berdasarkan PISA

Hasil studi PISA juga bersesuaian dengan hasil survey internasional Trend in International Mathematics and Science Survey (TIMSS) pada tahun 2015, Indonesia menduduki peringkat 49 dari 53 negara peserta TIMSS. Berdasarkan hasil survey tersebut, kemampuan pemecahan masalah matematika peserta didik di Indonesia masih di bawah standar Internasional.

Berkaitan dengan nilai Ujian Nasional (UN) jenjang SMA/MA (Tahun 2015, 2015, 2017, 2018, 2019 ; https://hasilun.puspendik.kemendikbud.go.id/) di Provinsi NTB mata ujian Matematika program studi IPA, khususnya materi statistika dan peluang, di semua satuan pendidikan semua kabupaten/kota nilai siswa pada 5 tahun terakhir mengalami penurunan. Walaupun penurunan yang terjadi tidak signifikan, namun standar kelulusan nilai UN yakni 52,00 dan nilai UN siswa berada di bawah standar kelulusan tersebut. Khususnya pada SMAN 1 Lembar Kabupaten Lombok Barat, kemampuan siswa dalam menjawab soal UN materi statistika dan peluang cukup rendah. Nilai UN siswa tahun 2015 masih sibawah standar kelulusan yakni 51,54 sedangkan nilai UN siswa tahun 2019 jauh dibawah standar kelulusan yaitu 25,94. Berkaitan dengan pemaparan hasil nilai UN tersebut, karena nilai UN siswa rendah dan dibawah standar kelulusan UN maka dapat diindikasikan bahwa siswa di SMAN 1 Lembar kurang mampu memahami dan memecahkan permasalahan matematika yang diberikan (https://hasilun.puspendik.kemendikbud.go.id/).

Penelitian mengenai kemampuan pemecahan masalah telah banyak dilakukan oleh peneliti-peneliti. Beberapa peneliti tersebut diantaranya Meika \& Sujana (2017) yang melakukan penelitian mengenai hubungan antara nilai UN siswa SMA kelas XII IPA yang berasal dari tiga sekolah berbeda dengan kemampuan pemecahan masalahnya. Melaui penelitian ini, disimpulkan bahwa SMA dengan nilai rata-rata UN yang lebih tinggi memiliki rata-rata kemampuan pemecahan masalah yang tinggi pula, begitupun sebaliknya SMA dengan nilai rata-rata yang UN rendah rata-rata kemampuan pemecahan masalahnya pun rendah. Penelitian mengenai kemampuan pemecahan masalah juga dilakukan oleh Akbar, dkk (2018) yang mengujikan soal peluang biasa pada siswa kelas XI SMA menggunakan 4 indikator kemampuan pemecahan masalah yaitu, memahami masalah, merencanakan penyelesaian, melaksanakan rencana dan memeriksa kembali proses dan hasil. Hasil penelitiannya menunjukkan bahwa kemampuan pemecahan masalah siswa pada materi peluang termasuk dalam kategori rendah. Hal ini terlihat dari pencapaian siswa pada 4 indikator yang ada, memahami masalah $48,75 \%$, merencanakan penyelesaian $40 \%$, menyelesaikan masalah $7,5 \%$ dan melakukan pengecekan $0 \%$. Penelitian lain yang dilakukan oleh Fatimah 
(2019) dengan mengujikan soal-soal statistika dari tahun-tahun sebelumnya kepada 38 siswa SMA, menunjukkan bahwa siswa dengan kemampuan pemecahan masalah kelompok atas lebih banyak dari pada siswa dengan kemampuan pemecahan masalah kelompok sedang dan kemampuan pemecahan masalah kelompok bawah.

Penelitian-penelitian yang dipaparkan diatas belum menggambarkan secara eksplisit mengenai kemampuan pemecahan masalah siswa dalam menyelesaikan soal-soal statistika berstandar UN dengan menggunakan 4 indikator pemecahan masalah yaitu, 1) Memahami masalah, 2) Merencanakan pemecahannya, 3) Menyelesaikan masalah sesuai rencana, 4) Memeriksa kembali prosedur dan hasil peneyelesaian. Berdasarkan uraian diatas, maka tujuan penelitian ini adalah untuk mengetahui Kemampuan Pemecahan Masalah Siswa Kelas XI IPA pada Soal Statistika Berstandar UN pada siswa dengan kemampuan awal matematika tinggi, sedang dan rendah. Informasi mengenai kemampuan pemecahan masalah siswa oleh guru dapat digunakan untuk meningkatkan pemahaman guru untuk mengetahui bentuk-bentuk soal pemecahan masalah, termasuk kesulitan, kesalahan dan hal-hal lainnya yang dapat digunakan sebagai salah satu bahan pertimbangan dalam mengajar.

\section{KAJIAN TEORI}

Menurut Morgan, dkk. (dalam Baharuddin \& Wahyuni, 2008) belajar merupakan perubahan tingkah laku dalam hal pemahaman, perilaku, persepsi, motivasi, atau gabungan dari semuanya yang relative tetap dan terjadi sebagai hasil latihan atau pengalaman. Dengan demikian, dalam belajar matematika maka akan terdapat suatu perubahan pada ranah kognitif, afektif, maupun psikomotor dari individu itu sendiri. Agar materi matematika yang diberikan dapat menunjang kebutuhan perkembangan anak, maka dalam pengembangan kurikulumnya perlu memperhatikan perkembangan kognitif anak dan kemampuan berpikirnya, serta tuntutan kemampuan dasar matematis yang diperlukan untuk melanjutkan studi ke jenjang yang lebih tinggi. Selain itu kemampuan berpikir matematis yang relevan menunjang kehidupan di masyarakat dan dunia kerja serta memungkinkan dikembangkan melalui kegiatan bermatematika. Salah satu aspek yang harus dikuasai siswa adalah kemampuan pemecahan masalah matematika.

Polya (1973) mengemukakan pemecahan masalah merupakan suatu usaha yang akan dilakukan oleh siswa dalam mencari jalan keluar atas kesulitan yang sedang dihadapi. Menurut Polya (dalam Mawaddah \& Anisah, 2015) terdapat 4 aspek kemampuan pemecahan masalah sebagai berikut: (1) Memahami masalah, pada aspek memahami masalah melibatkan pendalaman situasi masalah, melakukan pemilahan fakta-fakta, menentukan hubungan diantara fakta-fakta dan membuat formulasi pertanyaan masalah. Setiap masalah yang tertulis, bahkan yang paling mudah sekalipun harus dibaca berulang kali dan informasi yang terdapat dalam masalah dipelajari dengan seksama. (2) Membuat rencana pemecahan masalah, rencana solusi dibangun dengan mempertimbangkan struktur masalah dan pertanyaan yang harus dijawab. Dalam proses pembelajaran pemecahan masalah, siswa dikondisikan untuk memiliki pengalaman menerapkan berbagai macam strategi pemecahan masalah. (3) Melaksanakan rencana pemecahan masalah, untuk mencari solusi yang tepat, rencana yang sudah dibuat harus dilaksanakan dengan hatihati. Diagram, tabel atau urutan dibangun secara 
seksama sehingga si pemecah masalah tidak akan bingung. Jika muncul ketidakkonsistenan ketika melaksanakan rencana, proses harus ditelaah ulang untuk mencari sumber kesulitan masalah. (4) Melihat (mengecek) kembali, selama melakukan pengecekan kembali, solusi masalah harus dipertimbangkan. Solusi harus tetap cocok terhadap akar masalah meskipun kelihatan tidak beralasan.

Berkaitan dengan Ujian Nasional (UN), salah satu materi yang diujikan dalam UN untuk jenjang SMA dan sederajat yaitu materi statistika dan peluang. Materi statistika dan peluang yang mendominasi di soal UN 2015 - 2019 adalah soal rata-rata nilai hitung dan soal cerita untuk peluang. Bentuk soalnya biasanya berbentuk tabel, histogram dan soal cerita peluang. Berdasarkan penjelasan mengenai indikator pemecahan masalah, jenis soal yang mendukung yakni soal cerita. Soal dalam bentuk cerita biasanya menuntut siswa untuk memahami maksud dari soal tersebut hal ini sesuai dengan indikator kemampuan pemecahan masalah yang pertama, yaitu memahami masalah. Dari terpenuhnya indikator pertama tersebut, siswa tentunya akan menentukan 3 langkah selanjutnya.

\section{METODE}

Adapun jenis penelitian yang digunakan dalam penelitian ini adalah penelitian kualitatif dengan pendekatan penelitian deskriptif. Subjek dari penelitian ini adalah siswa kelas XI IPA semester genap SMAN 1 Lembar Kabupaten Lombok Barat sebanyak 6 orang siswa, 3 siswa perempuan dan 3 siswa laki-laki. Pemilihan subjek dilakukan berdasarkan nilai ulangan semester Tahun Pelajaran 2019/2020 pada materi Statistika, yang mana diperoleh 2 siswa dengan skor tertinggi, 2 siswa dengan skor sedang dan 2 siswa dengan skor rendah. Subjek dengan kategori kemampuan tinggi laki-laki diberikan kode (N1), subjek dengan kategori kemampuan tinggi perempuan diberikan kode (N2), subjek dengan kategori kemampuan sedang laki-laki diberikan kode (N3), subjek dengan kategori kemampuan sedang perempuan diberikan kode (N4), subjek dengan kategori kemampuan rendah laki-laki diberikan kode (N5) dan subjek dengan kategori kemampuan rendah perempuan diberikan kode (N6). Instrumen penelitian sederhana yang digunakan sebagai alat bantu dalam penelitian ini adalah soal uraian statistika berstandar UN dan peneliti sendiri. Soal uraian yang dimaksud adalah soal statistika berstandar UN sebanyak 3 soal uraian (Tabel 1) dan termasuk kategori kemampuan pemecahan masalah.

Tabel 1. Instrumen Soal

\begin{tabular}{|c|c|}
\hline No & Soal \\
\hline 1 & $\begin{array}{l}\text { Diketahui data }: 7,6,2, p, 3,4 \text {. Jika rata-rata dari data tersebut sama dengan } \\
\text { mediannya, banyaknya nilai } p \text { yang mungkin untuk } p \text { bilangan asli adalah... }\end{array}$ \\
\hline 2 & $\begin{array}{l}\text { Di suatu kelas terdiri dari siswa yang dibagi menjadi } 3 \text { kelompok untuk } \\
\text { member sumbangan kepada korban bencana alam. Kelompok I, II dan III } \\
\text { berturut-turut terdiri dari 10, } 12 \text { dan } 18 \text { siswa. Jika rata-rata sumbangan } \\
\text { kelompok I adalah Rp.10.000,-, rata-rata sumbangan kelompok II } \\
\text { Rp.11.000,- dan rata-rata sumbangan seluruh kelompok adalah Rp.9.400,- } \\
\text { maka rata-rata sumbangan kelompok III adalah? }\end{array}$ \\
\hline 3 & Perhatikan histogram berikut. \\
\hline
\end{tabular}




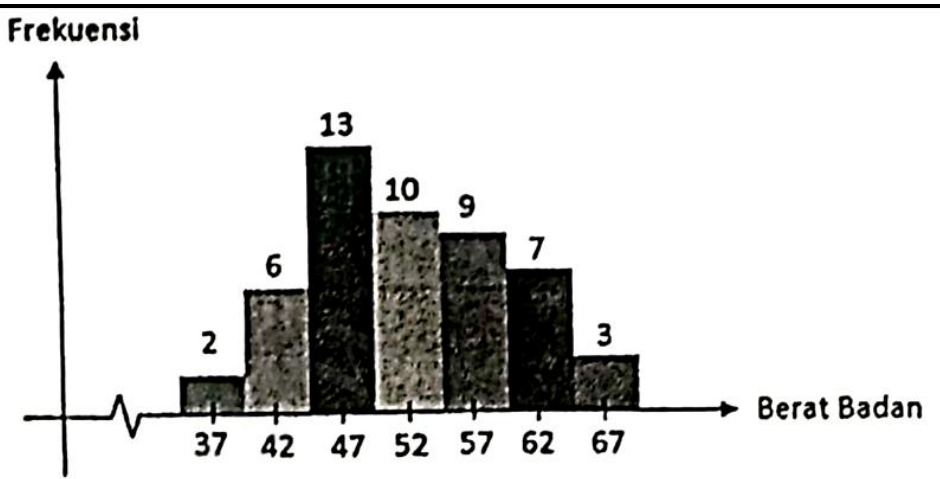

Kuartil ke-2 dari data berat badan yang ditunjukkan pada histogram diatas adalah

Peneliti akan menganalisis lembar jawaban siswa dari tes yang telah diberikan untuk menyesuaikan jawaban dengan indikator pemecahan masalah yang telah ditentukan. Wawancara dilakukan dengan cara penyampaian sejumlah pertanyaan dari pewawancara kepada narasumber. Jenis wawancara yang digunakan adalah wawancara terstruktur dimana peneliti menggunakan pedoman wawancara yang telah tersusun secara sistematis dan lengkap untuk pengumpulan datanya. Berikut pedoman wawancara yang akan digunakan oleh peneliti. Analisis data dilakukan dalam penelitian ini adalah menganalisis hasil jawaban siswa dengan kesesuaian jawaban yang memenuhi 4 indikator kemampuan pemecahan masalah yang diadaptasikan dari Akbar, dkk (2018) seperti disajikan pada Tabel 2.

Tabel 2. Indikator Kemampuan Pemecahan Masalah Siswa

\begin{tabular}{ll}
\hline \multicolumn{1}{c}{ Indikator } & \multicolumn{1}{c}{ Respon terhadap soal } \\
\hline $\begin{array}{l}\text { Memahami masalah } \\
\text { perencanakan }\end{array}$ & $\begin{array}{l}\text { Dapat mengidentifikasi unsur-unsur yang diketahui, } \\
\text { ditanyakan, dengan lengkap dan benar. }\end{array}$ \\
$\begin{array}{l}\text { Menyelesaikan masalah } \\
\text { sesuai rencana }\end{array}$ & $\begin{array}{l}\text { Ada penyelesaian, proses perhitungan benar dan hasil } \\
\text { akhir benar. }\end{array}$ \\
$\begin{array}{l}\text { Memeriksa kembali } \\
\text { prosedur dan hasil } \\
\text { penyelesaian }\end{array}$ & Kesimpulan yang diberikan benar. \\
\hline
\end{tabular}

\section{HASIL DAN PEMBAHASAN}

Berdasarkan hasil penelitian berupa hasil tes yang telah dilakukan, diketahui bahwa terdapat beberapa persamaan dan perbedaan kemampuan siswa dalam menyelesaikan soal berdasarkan tahapan Polya, seperti yang dijelaskan secara rinci berikut.

\section{Siswa dengan Kemampuan Awal Matematika Tinggi dalam Menyelesaikan Soal Statistika Berstandar UN}

Berdasarkan lembar jawaban siswa, subjek N1 dapat menuliskan kembali informasi apa saja yang diketahui untuk setiap nomor soal. Akan tetapi, yang dituliskan hanyalah berupa data yang termuat dalam soal dengan beberapa 
singkatan kata yang dipahami oleh subjek, tanpa memberikan informasi tambahan lainnya. N1 juga tidak menuliskan bagian yang ditanyakan pada soal (lihat Gambar 1).

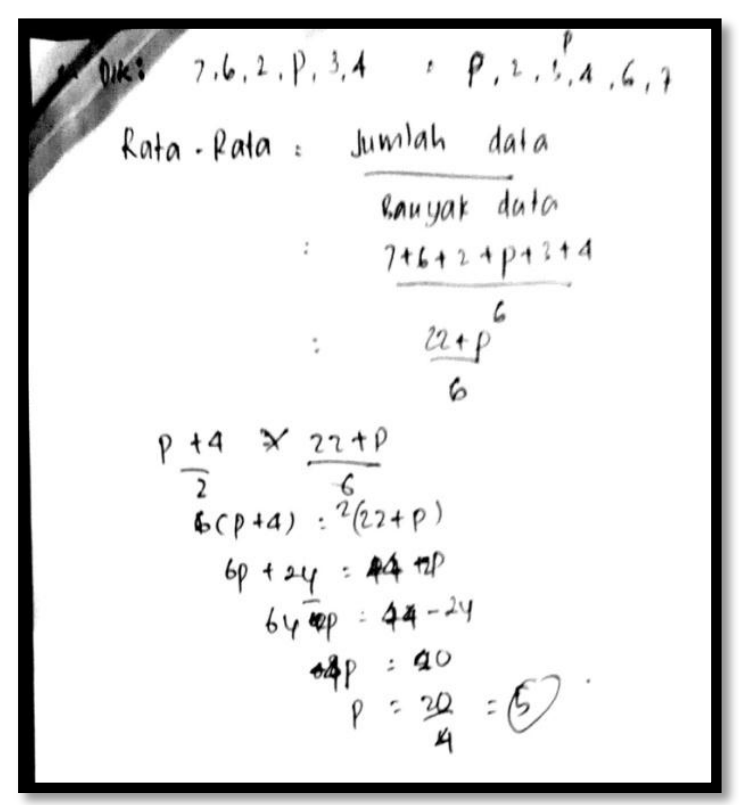

Gambar 1. Jawaban N1 untuk Soal Nomor 1

Hal yang sama juga terjadi pada subjek N2 untuk soal nomor 2, sedangkan pada soal nomor 1, dia tidak menuliskan informasi yang diketahui dan ditanyakan dalam soal. N2 bahkan tidak bisa memahami apa yang diketahui dan ditanyakan pada soal nomor 3. Setelah dikonfirmasi melalui wawancara, diperoleh fakta bahwa N1 dan N2 ternyata belum cukup memahami masalah dengan baik pada beberapa soal yang diberikan. Berikut cuplikan wawancara peneliti $(\mathrm{P})$ dengan N1 dan $\mathrm{N} 2$.

$P \quad$ : Apa yang Anda pahami dari soal 1?

N1 : Pada soal nomor 1, yang ditanyakan adalah berapa nilai p. Di sini $p$ adalah median, sehingga saya letakkan di tengah. Berdasarkan soal juga diketahui bahwa median sama dengan rata-rata.

N2 : Saya tuliskan apa yang diketahui dari soal.

$P \quad: \quad$ Bagaimana dengan soal nomor 2?

N1 : Saya tentukan apa yang diketahui dan saya kelompokkelompokkan seperti yang saya tuliskan pada lembar jawaban.

N2 : Pada soal nomor 2 diminta untuk mencari rata-rata sumbangan kelompok III sedangkan yang diketahui hanya kelompok I dan II juga rata-rata keseluruhannya.

$P \quad: \quad$ Bagaimana pula dengan soal nomor 3?

N1 : Untuk soal nomor 3, bagian yang ditanyakan adalah Q2 atau sama dengan median kemudian saya tuliskan datanya.

N2 : Saya tidak mengerti, Bu.

Berdasarkan hasil wawancara tersebut, N1 menuliskan semua data yang diketahui oleh soal untuk semua nomor soal, akan tetapi, N1 belum memahami 
maksud soal tersebut. Sebagai contoh, pada soal nomor 1 N1 dengan yakin mengatakan bahwa $\mathrm{p}$ adalah median padahal dalam soal tidak ada informasi yang mengatakan bahwa p merupakan median atau bukan median. Soal meminta subjek untuk mencari nilai p yang mungkin sedemikian sehingga mean dan median pada data tersebut sama. Berbeda dengan soal nomor 1, pada soal nomor 2 dan 3 N1 sudah cukup memahaminya. Untuk subjek $\mathrm{N} 2$, hasil wawancara tidak menunjukkan bagaimana kedalaman pemahaman subjek terhadap soal nomor 1 dan 2 karena saat ditanyai subjek hanya menjawab bahwa dia telah menuliskan apa yang diketahui dari soal. Meskipun demikian, subjek sempat mengulang kembali secara ringkas pemahamannya mengenai soal nomor 2 dengan katakatanya sendiri, sedangkan pada soal nomor 3 N2 mengaku tidak memahami maksud dari soal.

Pada penelitian ini, tahap merencanakan pemecahan dianalisis bersamaan dengan tahap menyelesaikan masalah sesuai rencana. Oleh karena N1 dan N2 belum mampu memahami maksud dari soal 1 dengan baik, maka N1dan N2 juga belum tepat dalam merencanakan pemecahan dan menyelesaikannya. Pada soal nomor 2, N1 mencari nilai rata-rata sumbangan siswa pada kelompok 3 dengan melalui rumus rata-rata sumbangan seluruh siswa pada kelas tersebut. Akan tetapi, $\mathrm{N} 1$ salah dalam menggunakan rumus penyelesaian karena dia menganggap bahwa rata-rata keseluruhan sumbangan diperoleh dengan menghitung jumlah rata-rata sumbangan kelompok 1, kelompok 2 dan kelompok 3 kemudian dibagi dengan banyaknya kelompok, yaitu 3 (lihat Gambar 2). Padahal, rata-rata sumbangan seluruh kelompok diperoleh dengan menambahkan seluruh sumbangan yang diberikan setiap siswa mulai dari siswa pada kelompok 1, kelompok 2, sampai siswa pada kelompok 3 kemudian dibagi dengan seluruh banyaknya siswa pada kelas tersebut yang dihitung dengan menjumlahkan banyaknya siswa pada setiap kelompok, yaitu $10+12+18=40$. Dengan cara lain, subjek juga sebenarnya bisa menentukan rata-rata sumbangan siswa pada kelompok 3 melalui rumus ratarata keseluruhan seperti berikut,

Misalkan

$$
\begin{aligned}
& \text { rata - rata sumbangan siswa pada kelompok } I=A, \\
& \text { rata - rata sumbangan siswa pada kelompok } I I=B, \\
& \text { rata - rata sumbangan siswa pada kelompok } I I I=C, \\
& \text { rata - rata sumbangan keseluruhan }=D, \\
& \text { banyaknya siswa pada kelompok } I=x, \\
& \text { banyaknya siswa pada kelompok } I I=y, \\
& \text { banyaknya siswa pada kelompok } I I I=z,
\end{aligned}
$$

maka

$$
D=\frac{x \cdot A+y \cdot B+z \cdot C}{x+y+z}
$$

Pada soal nomor 3, N1 memahami bahwa bilangan yang berada di atas histogram, yaitu 2, 6, 13, 10, 9, 7 dan 3, sebagai datanya sehingga dia langsung mengurutkan data dan menentukan menentukan median data sesuai dengan rumus median pada data ganjil. Padahal, bilangan-bilangan ini menunjukkan frekuensi dari masing-masing kelompok data. Oleh sebab itulah, jawaban N1 salah. Berbeda 
dengan N1 yang masih berusaha menyelesaikan permasalahan dalam soal, N2 tidak berhasil menyelesaikan soal nomor 2 dan tidak mengerjakan soal nomor 3 sama sekali.

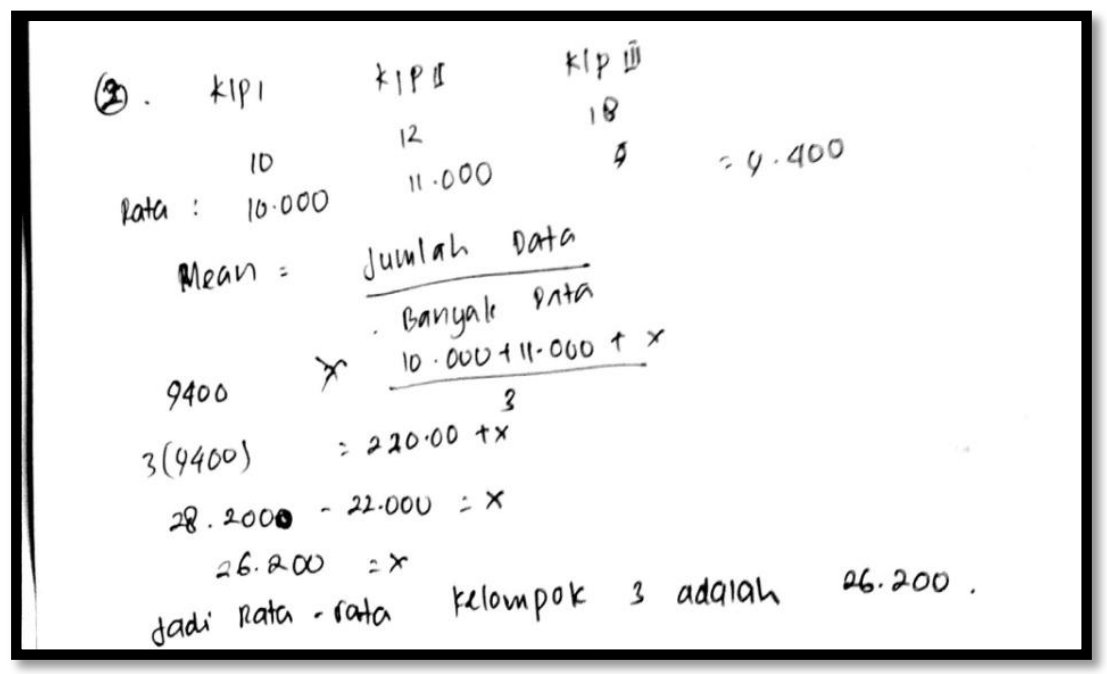

Gambar 2. Jawaban N1 untuk Soal Nomor 2

Terkait dengan tahap memeriksa kembali prosedur dan hasil penyelesaian, kedua subjek tidak memeriksa kembali jawaban yang telah dibuat dan tidak semua soal dituliskan kesimpulan. Kedua subjek cenderung tidak menuliskan kembali kesimpulan akhir dari soal yang telah dikerjakan namun dapat menjelaskan kesimpulan akhir dari soal. Berdasarkan uraian tersebut, maka dapat disimpulkan bahwa untuk soal nomor 1 dan 2, baik N1 maupun N2 hanya mampu sampai pada tahap pertama Polya, yaitu tahap memahami masalah.

\section{Siswa dengan Kemampuan Awal Matematika Sedang dalam Menyelesaikan Soal Statistika Berstandar UN}

Hasil analisis pemahaman masalah subjek N3 pada lembar jawaban menunjukkan bahwa N3 tidak menuliskan informasi apapun mengenai hal-hal yang diketahui dan ditanyakan pada soal. Setelah dikonfirmasi melalui wawancara, diperoleh fakta bahwa N3 sebenarnya cukup memahami ketiga soal meskipun soal pertama dan kedua berhasil dikerjakan dengan cara yang tidak tepat. Pada soal pertama, N3 mengerti bahwa nilai $p$ yang akan ditentukan, namun strategi yang diambil dalam menentukan nilai $p$ salah. N3 mencari nilai $p$ dengan mencari rata-rata lima nilai yang lain. Bersesuaian dengan soal nomor 1, N3 juga melakukan kesalahan dalam mengerjakan soal nomor 2 karena N3 mencari nilai rata-rata sumbangan kelompok 3 dengan menjumlahkan nilai rata-rata sumbangan kelompok 1, rata-rata sumbangan kelompok 2 dan rata-rata sumbangan seluruh kelompok yang kemudian dibagi dengan 12 atau banyaknya siswa pada kelompok 3 seperti Gambar 3. Berbeda dengan soal 1 dan 2, pada soal nomor 3, N3 mengaku sama sekali tidak memahami maksud dari soal. 


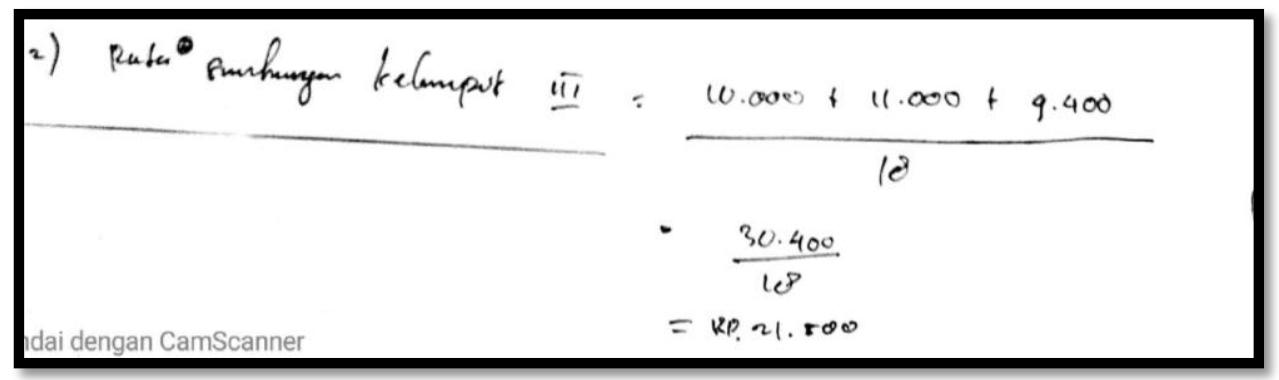

Gambar 3. Jawaban N3 untuk Soal Nomor 2

Pada tahap memahami masalah subjek N4 dapat menuliskan apa yang diketahui dari soal, hanya saja subjek N4 memiliki kebiasaan untuk tidak menuliskan kembali apa yang ditanyakan dari soal. Langkah penyelesaian soal nomor 1 dan 2 yang digunakan oleh $\mathrm{N} 4$ sama dengan langkah yang dikerjakan oleh N1 (Gambar 4). Akan tetapi, untuk soal nomor 3, N4 mengaku tidak memahami apa yang dimaksud dengan kuartil. N3 dan N4 juga tidak memeriksa kembali jawaban yang telah dibuat. Dengan kata lain, N3 dan N4 hanya berhasil sampai pada tahap memahami masalah.

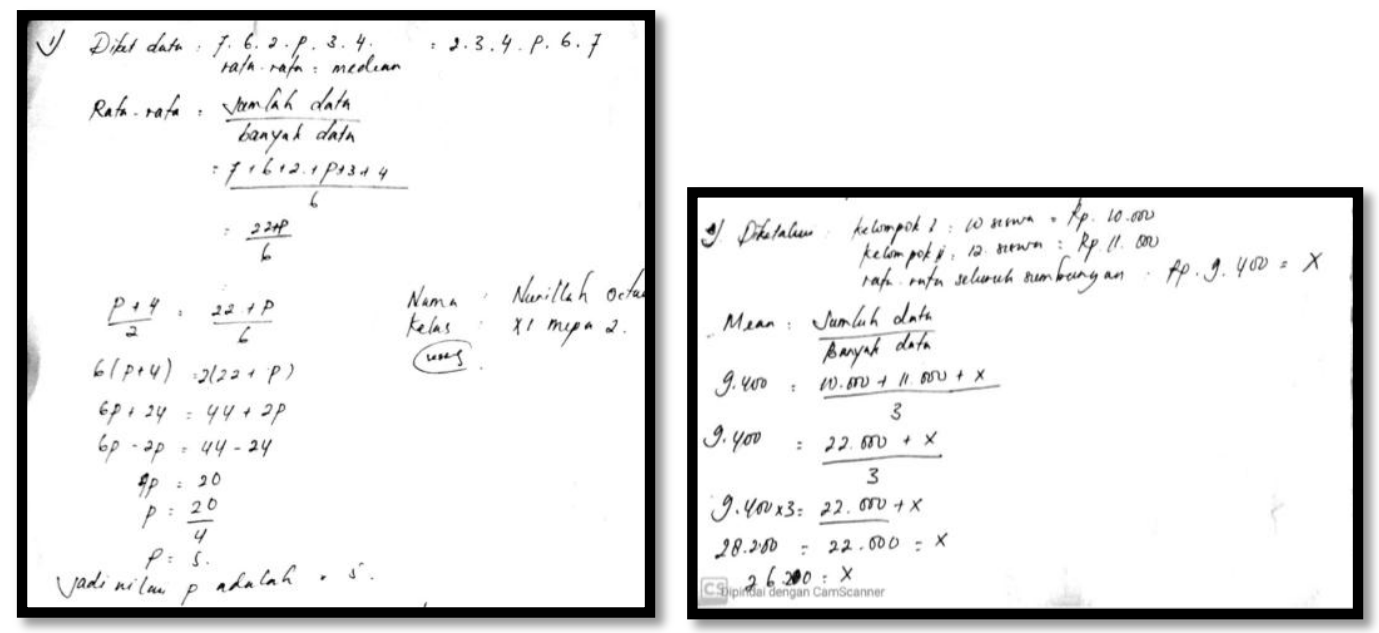

Gambar 4. Jawaban N4 untuk Soal Nomor 1 dan 2

\section{Siswa dengan Kemampuan Awal Matematika Rendah dalam Menyelesaikan Soal Statistika Berstandar UN}

Subjek N5 tidak menuliskan apa yang diketahui dan ditanyakan dari soal pada lembar jawaban. Meskipun demikian, N5 dapat menyebutkan apa yang diketahui dan ditanyakan untuk soal nomor 1 dan 2 pada saat diwawancara. Khusus pada soal nomor 3, N5 mengaku tidak memahami maksud soal karena ini pertama kalinya dia menemukan soal tersebut.

$P \quad$ : Bagaimana dengan soal nomor 3?

N5 : Kalau nomor 3 saya tidak paham, benar-benar tidak tahu karena tumben saya lihat soal seperti ini. 
Strategi yang digunakan N5 dalam menyelesaikan soal bukan merupakan strategi yang benar karena untuk menjawab soal nomor 1, N5 memisalkan median $=p$ pada bagian awal langkah penyelesaian. Pada langkah selanjutnya, N5 mencari nilai $\mathrm{p}$ dengan menggunakan rumus rata-rata dari lima nilai data yang lain (Gambar 5). Langkah ini serupa dengan langkah yang dilakukan oleh N3.

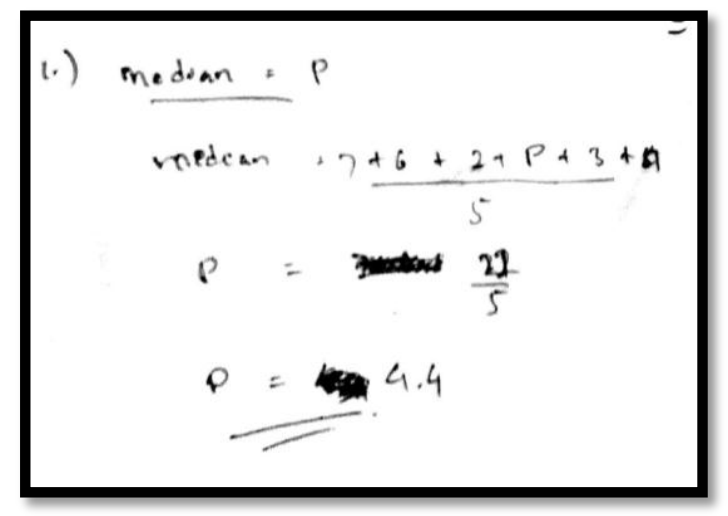

Gambar 5. Jawaban N5 untuk Soal Nomor 1

Strategi yang digunakan N5 untuk menyelesaikan soal nomor 2 juga sama dengan yang dilakukan oleh N3. Berbeda dengan N5, N6 tidak menyelesaikan semua soal karena tidak memahami soal yang diberikan.

Berdasarkan hasil tes dari 6 subjek penelitian, pencapaian kemampuan pemecahan masalah siswa terbilang sangat rendah karena rata-rata hanya mencapai tahap memahami masalah seperti yang dapat dilihat pada Tabel 3 . Pemahaman masalah siswa juga hanya terbatas pada bagian yang diketahui dan ditanyakan oleh soal dengan sebagian besar siswa hanya menuliskan data saja tanpa menuliskan apa yang ditanyakan. Meskipun demikian, pemahaman siswa mengenai maksud dari soal masih diragukan. Bahkan, tidak semua siswa menuliskan apa yang diketahui dan ditanyakan untuk setiap nomor soal. Lebih jauh, siswa sebenarnya belum menguasai dan memahami permasalahan dalam setiap soal yang diberikan sehingga menimbulkan berbagai macam kesalahan dan kekeliruan (Agustiva, Ndia \& Ikman, 2016; Rahayu \& Purwasih, 2020) yang disebabkan oleh rendahnya kemampuan pemahaman matematis siswa pada materi statistika (Mediyani \& Mahtuum, 2020). Ketidaktepatan siswa dalam menggunakan rumus ketika menyelesaikan permasalahan tergolong dalam kesalahan konsep yang dimungkinkan terjadi karena kemampuan kognitif siswa yang rendah, termasuk kurangnya pemahaman siswa pada soal atau konsep statistika, kesalahan dalam menafsirkan maksud dari soal serta ketidakmampuan dalam memahami langkah penyelesaian soal (Muammanah, Subaidi \& Supardi, 2016) dan melakukan manipulasi statistik (Dewi, Khodijah \& Zanthy, 2020). Hal ini berakibat pada kesalahan strategi dan langkah penyelesaian yang digunakan. Hasil ini didukung juga dengan hasil penelitian Mahdayani (2016) yang menyatakan bahwa lebih dari 50\% siswa mengalami kesulitan dalam membaca, memahami, mentransformasi, menentukan strategi atau memproses dan menarik kesimpulan jika ditinjau dari langkah pemecahan masalah. Namun demikian, ada juga beberapa siswa yang sebenarnya memahami maksud soal tetapi salah dalam menentukan penyelesaian. 
Tabel 3. Pencapaian Kemampuan Pemecahan Masalah Siswa

\begin{tabular}{ccccc}
\hline No. & Subjek & $\begin{array}{c}\text { Kemampuan awal } \\
\text { matematika }\end{array}$ & P/L & $\begin{array}{c}\text { Capaian tahapan kemampuan } \\
\text { pemecahan masalah }\end{array}$ \\
\hline 1 & N1 & Tinggi & L & Tahap memahami masalah \\
2 & N2 & Tinggi & P & Tahap memahami masalah \\
3 & N3 & Sedang & L & Tahap memahami masalah \\
4 & N4 & Sedang & P & Tahap memahami masalah \\
5 & N5 & Rendah & L & Tahap memahami masalah \\
6 & N6 & Rendah & P & Tidak mengerjakan sama sekali \\
\hline
\end{tabular}

\section{SIMPULAN DAN SARAN}

Berdasarkan hasil dan pembahasan maka dapat disimpulkan bahwa sebagian besar siswa hanya memiliki kemampuan pemecahan masalah hingga pada tahap memahami masalah. Dengan kata lain, kemampuan pemecahan masalah siswa sangat rendah untuk semua subjek yang terlibat. Pada tahap memahami masalah, dari hasil tes tertulis ada 3 siswa yang dapat memahami masalah dengan menuliskan apa yang diketahui dan ditanyakan dari soal, yaitu 2 siswa dengan kemampuan awal matematika tinggi dan 1 siswa dengan kemampuan awal matematika sedang, sedangkan pada tahap merencanakan pemecahan dan menyelesaikan permasalahan belum ada satu pun siswa yang dapat menyelesaikan masalah dengan benar. Seluruh siswa tidak memeriksa kembali setiap langkah yang digunakan dan jawaban yang diperoleh.

Penelitian selanjutnya diharapkan dapat menganalisis lebih mendalam penyebab siswa dengan kemampuan awal matematika tinggi dan sedang tidak dapat menyelesaikan soal dan siswa dengan kemampuan awal matematika rendah tidak dapat memahami soal. Peneliti juga diharapkan dapat menentukan cara yang lebih tepat dalam menentukan subjek untuk hasil sesuai harapan, menentukan jenis soal yang tepat yaitu soal dengan kategori LOTS atau HOTS serta mengidentifikasi apakah jenis tersebut telah diterima oleh siswa serta kategori dari soal yang telah dipelajari sebelumnya.

\section{DAFTAR RUJUKAN}

Agustiva, W. O., Ndia, L. \& Ikman. (2016). Analisis Kesalahan Siswa Dalam Menyelesaikan Soal Statistika (Studi Kualitatif Pada Siswa Kelas VII SMP Negeri 4 Kendari). Jurnal Penelitian Pendidikan Matematika, 4(1), 155168.

Akbar, P., Hamid, A., Bernard, M., \& Sugandi, A. I. (2018). Analisis kemampuan pemecahan masalah dan disposisi matematik siswa kelas XI SMA Putra Juang dalam materi peluang. Jurnal Cendekia: Jurnal Pendidikan Matematika, 2(1), 144-153.

Depdiknas. (2006). Panduan Penyusunan Kurikulum Tingkat Satuan Pendidikan. Badan Standar Nasional Pendidikan: Jakarta.

Dewi, D. K., Khodijah, S. S., \& Zanthy, L. S. (2020). Analisis kesulitan matematik siswa SMP pada materi statistika. Jurnal Cendekia: Jurnal Pendidikan Matematika, 4(1), 1-7.

Fatimah, C. T. (2019). Analisis Kemampuan Pemecahan Masalah Siswa Kelas XII Materi Statistika Pada Soal UN. EDUSAINTEK, 3. 
Mahdayani, R. (2016). Analisis kesulitan siswa dalam pemecahan masalah matematika pada materi aritmatika, aljabar, statistika, dan geometri. Jurnal Pendas Mahakam, 1(1), 86-98.

Mawaddah, S., \& Anisah, H. (2015). Kemampuan pemecahan masalah matematis siswa pada pembelajaran matematika dengan menggunakan model pembelajaran generatif (generative learning) di SMP. EDU-MAT: Jurnal Pendidikan Matematika, 3(2).

Mediyani, D., \& Mahtuum, Z. A. R. (2020). Analisis Kesulitan Siswa Dalam menyelesaikan Soal Materi Statistika Pada Siswa SMP Kelas VIII. JPMI (Jurnal Pembelajaran Matematika Inovatif), 3(4), 385-392.

Meika, I., \& Sujana, A. (2017). Kemampuan berfikir Kreatif dan Pemecahan Masalah Matematis Siswa SMA. JPPM. 10(2): 28-13

Muammanah, Subaidi, A., \& Supardi, L. (2018). Analisis Kesalahan Siswa MA Al-Falah Branta Tinggi dalam Menyelesaikan Soal UN Matematika Pokok Bahasan Statistika Kelas XI. Jurnal Pendidikan Matematika dan Integrasinya, 2(1), 56-64.

National Council of Teacher of Mathematics. 2000. Principles and Standards for School Mathematics. Reston, VA: Author.

PISA. (2015). Assessment and Analytical Framework: Mathematics, Reading, Science, Problem Solving and Financial Literacy. Paris: OECD.

PISA. (2012). Assessment and Analytical Framework: Mathematics, Reading, Science, Problem Solving and Financial Literacy. Paris: OECD.

Polya, G. (1973). How to solve it a new aspect of mathematical method. New Jersey: Princeton University Press.

Rahayu, O. P., \& Purwasih, R. (2020). Analisis Kesalahan dalam Materi Statistika pada Siswa SMP Kelas IX Berdasarkan dari Perspektif Gender. JPMI (Jurnal Pembelajaran Matematika Inovatif), 3(5), 451-462.

Sapitri, Y., Utami, C., \& Mariyam, M. (2019). Analisis kemampuan pemecahan masalah matematis siswa dalam menyelesaikan soal open-ended pada materi lingkaran ditinjau dari minat belajar. Variabel, 2(1), 16-23.

Wiwin, T. T., \& Mogi, Y. (2016). Analisis Kemampuan Pemecahan Masalah Matematika Ssiswa dalam Menyelesaikan Soal Rata-rata Hitung. In Prosiding Seminar Nasional Reforming Pedagogy (Vol. 234). 